Ambiente \& Água - An Interdisciplinary Journal of Applied Science
ISSN 1980-993X - doi:10.4136/1980-993X
www.ambi-agua.net
E-mail: ambi-agua@agro.unitau.br

\title{
Tissue levels of the antioxidant enzymes superoxide dismutase and catalase in fish Astyanax bimaculatus from the Una River Basin
}

\author{
doi: 10.4136/ambi-agua.1473
}

Received: 26 Jul. 2014; Accepted: 29 Sep. 2014

\author{
Maria Tereza Oliveira Batista ${ }^{1}$; Edson Rodrigues Junior ${ }^{2}$; \\ Mariana Feijó-Oliveira ${ }^{2}$; Anne Caroline Ribeiro'; \\ Edson Rodrigues ${ }^{1}$; Cecilia Nahomi Kawagoe Suda ${ }^{1}$; \\ Gannabathula Sree Vani ${ }^{*}$ \\ ${ }^{1}$ Universidade de Taubaté, (UNITAU), Taubaté, SP, Brasil \\ ${ }^{2}$ Universidade Federal do Paraná (UFPR), Curitiba, PR, Brasil \\ *Corresponding author: e-mail: srvani@ hotmail.com, \\ maria.tereza@gmail.com, edsonrodj@gmail.com,mari.feijo@bol.com.br, \\ aninha_3001@hotmail.com,rodedson@gmail.com,cnksuda@hotmail.com
}

\begin{abstract}
This paper seeks to identify the biomarker response to oxidative stress in Astyanax bimaculatus, a freshwater fish, collected from the Una River and its associated water bodies. The fish were collected using fishing nets at three different points on the river basin, namely Fazenda Piloto (FP), Ipiranga (IP) and Remédios (RM), during the period from December 2013 to March 2014. Physical and chemical analyses of the water at the sample locations indicate that IP and RM possibly have larger concentration of either natural or anthropic pollutants as compared to FP. FP can therefore be considered as the point less impacted by pollutants than other points. Hepatic activity of antioxidant stress enzymes, superoxide dismutase (SOD) and catalase (CAT), were measured in the specimens. The levels of SOD were reduced at RM while they were elevated in fish collected at IP. The CAT levels for the fish at RM and IP were about $148.9 \%$ and $202.4 \%$ above the values at FP, respectively. These results suggest that antioxidant enzymes could be used as biomarkers to measure oxidative stress caused by pollutants in the Una River Basin.
\end{abstract}

Keywords: biomonitoring, pollution, radical oxygen species.

\section{Níveis teciduais das enzimas antioxidantes superóxido dismutase e catalase no peixe Astyanax bimaculatus da bacia hidrográfica do rio Una}

\section{RESUMO}

O presente trabalho teve como objetivo identificar respostas de biomarcadores de estresse oxidativo no peixe de água doce Astyanax bimaculatus, coletado nos rios e corpos d'água da bacia hidrográfica do rio Una. Os peixes foram coletados com rede de pesca entre dezembro de 2013 e março de 2014, em três diferentes pontos da bacia: Fazenda Piloto (FP), Ipiranga (IP) e Remédios (RM). Análises físico-químicas das amostras de água nos pontos de coleta indicaram que IP e RM possivelmente apresentaram uma maior concentração de poluentes, naturais ou antrópicos, quando comparados ao FP. Portanto, FP pode ser considerado como o 
ponto menos impactado por poluentes em relação aos outros pontos. Níveis hepáticos de atividade das enzimas antioxidantes superóxido dismutase (SOD) e catalase (CAT) foram medidos nos espécimes. Os níveis de SOD foram reduzidos no RM, enquanto que eles foram aumentados em peixes coletados em IP. Os níveis de CAT nos peixes coletados em RM e IP foram $148,9 \%$ e $202,4 \%$ maiores do que os valores encontrados nos peixes do ponto FP, respectivamente. Os resultados sugerem que as enzimas antioxidantes podem ser usadas como biomarcadoras para mensurar os níveis de stress oxidativo causado pelos poluentes na bacia hidrográfica do rio Una.

Palavras-chave: biomonitoramento, espécies reativas de oxigênio, poluição.

\section{INTRODUCTION}

River ecosystems are extremely vulnerable to alterations in the environment due either to natural changes or to anthropic activities. Globally, the biodiversity of freshwater ecosystems has been reduced drastically as a result of human activity (Dahl et al., 2004). The runoff water from agriculture containing fertilizers, pesticides and herbicides, discharge of untreated sewage from urban areas, and heavy metals present in the effluents discharged from industries as well as mining along the river banks are the principal causes of river water pollution. Increasing urbanization and industrialization generate increasing amounts of waste that are dumped directly into freshwater bodies, thereby the lowering the quality of water (Beasley and Kneale, 2003). A large number of studies have shown the negative effect of different pollutants on the aquatic biota resulting in the loss of biodiversity and making the water unfit for life

Water quality, as measured by the physical and chemical parameters, does not give a long-term integrated view of the effect of pollution. The visibly debilitating effects of pollution on organisms in an ecosystem develop over a long period, and by the time they become conspicuous it may already be too late to reverse the degradation of the ecosystem or economically infeasible to take corrective action. It is therefore necessary to investigate methods that lead to early detection of harmful changes in the environment. Biomonitoring, which uses organisms to indicate the health of the environment, is well suited to this purpose as the existing organisms are adapted to the specific ecosystem and any alterations in the environment are reflected in the composition and structure of the biological communities (Alba-Tercedor, 1996; Fonseca et al., 2014). Both invertebrates and vertebrates have been used for bio-monitoring a river. Since fishes occupy an intermediate range in the food pyramid, they are ideally suited for bio-monitoring. Fishes of the genus Astyanax have been used to study the genotoxicity of the aquatic environments (Moreira et al., 2010), and their feasibility as biomarkers of pollution has been investigated (Trujillo-Jiménez et al., 2011).

One method of bio-monitoring is to use biomarkers. Biochemical biomarkers are molecules that are present in the body fluids, cells and tissues of organisms and whose activity is altered by the presence of toxic agents in the environment (McCarthy and Shugart, 1990). One important set of biomarkers is the antioxidant defense enzymes that decompose the Reactive Oxygen Species (ROS). These enzymes have an important role in the control, production and elimination of ROS, which in excess can alter the normal functions of the cell and lead to oxidation of the cell membranes as well as lesions in mitochondria, proteins, DNA and other components of the cell. Natural or anthropic changes in the environment introduce oxidative stress that results in disequilibrium in the cell by increasing the production of ROS (Lushckak, 2011). Superoxide dismutase (SOD) and catalase (CAT) are members of the antioxidant defense enzymes. SOD converts superoxide radicals into hydrogen peroxide. It has been shown that SOD activity is altered in mussels living in areas contaminated by heavy metals and organic pollutants (Binelli and Cogni 2010). The enzyme CAT is widely 
distributed in biological tissues and is involved in the decomposition of hydrogen peroxide into oxygen and water. It is one of the most prominent enzymes involved in defense against oxidative stress in both vertebrates and invertebrates (Goyal and Basak, 2010).

This paper discusses the biomonitoring of the Una River. The Una River Basin is formed by the union of the Ribeirão das Almas Stream with the Rocinha River and its effluents (Itaim, Ribeirão das Pedras or Ipiranga, Ribeirão das Sete Voltas, Rio das Antas, Ribeirão do Registro and other effluents). The basin has an area of $442,85 \mathrm{~km}^{2}$ with $8 \%$ in the municipality of Pindamonhangaba, $8 \%$ in the municipality of Tremembé and the rest $(84 \%)$ in the municipality of Taubaté. Geographically, the Una River Basin is on the right bank of the Paraíba do Sul River. The altitude of the basin varies between 500 to $1000 \mathrm{~m}$ (http://www.agro.unitau.br/una/una_plano_bacias_04.html). The importance of the Una River Basin and its tributaries became evident during the evaluation of the Paraíba do Sul River by the Committee on the Hydrography of Paraíba do Sul (CBH-PS). The Committee established a number of guidelines for the effective use and preservation of the river and all of its tributaries. Of the important guidelines established, priority was given to the water supply for public consumption, controlling the rate of urbanization of the basin, resolving conflicts arising from the use of the river water for multiple purposes, restoration of the soils, restoration of the riparian zones and the recuperation of the basin (Batista et al., 2002).

This paper studies the response to oxidative stress in the fish Astyanax bimaculatus, collected at various locations in the Una River Basin. Specifically, it investigates the hepatic levels of SOD and CAT as candidate biomarkers of antioxidant defense in this species.

\section{MATERIAL AND METHODS}

\subsection{Sample collection}

Sampling sites were selected based on the presence of plantations, untreated sewage discharge and regions where there was less human activity near the river or its tributaries. The geographic coordinates of the sites were determined using GPS. The sites used to collect the fish were: 1) Fazenda Piloto (FP), in the Ribeirão Itaim stream located inside Fazenda Piloto (an experimental farm) of the University of Taubaté, S23 $01^{\prime} 38.3^{\prime}$ W045 30'31.6"; 2) Remédios (RM), a ditch which flows to Una River, located in the municipality of Remédios, $\mathrm{S} 23^{\circ}$ 03'26.4' 'W045 $35^{\circ} 23.5^{\prime \prime}$, close to rice cultivation; 3) Ipiranga (IP), a lake near a pasture for cattle and near the municipal highway Dr. José Luiz Cembranelli, S2301'49.4" W45030'16.7" (Figure 1). The last site was visibly polluted and had oil-like slicks on the water surface. The specimen sampling was approved by MMA - SISBIO (authorization No. 41097-1). A single sampling of five specimens of the fish Astyanax bimaculatus (locally called lambari) was collected at each of the three locations between December 2013 and March 2014. A size 20 nylon fishing net was cast in the water and left for a period of 20 minutes, after which any fish that were caught in the net were retrieved and immediately transferred into a large bucket filled with water from that location. The 20 minute interval was used to ensure that the fish caught in the net did not suffer undue stress that could affect the experiment. The fish were photographed for later identification, dissected on an ice tray, and the hepatic tissue was retrieved and transferred to eppendorf tubes which were labeled and kept in ice until transported to the biochemistry laboratory of the Institute of Basic Biosciences (IBB), University of Taubate (UNITAU), where they were stored in a freezer at $86^{\circ} \mathrm{C}$ for further analysis. 


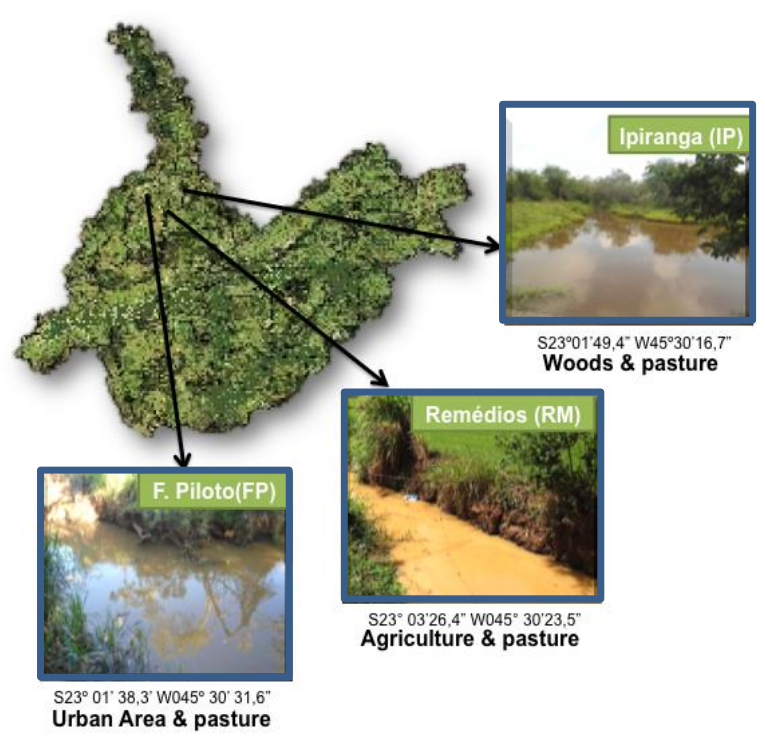

Figure 1. Hydrographic basin of the Una River and the three sites from which fish specimens were collected.

Source: http://www.agro.unitau.br/una.

Samples of the water were also collected for analysis of the physical and chemical parameters. The samples were collected in $300 \mathrm{~mL}$ glass bottles, stored in ice and transported to the water analysis laboratories of Department of Civil Engineering and Department of Agricultural Sciences, University of Taubaté, where they were kept refrigerated between $0^{\circ}$ a $5^{\circ} \mathrm{C}$. The values of $\mathrm{pH}$, hardness, chemical oxygen demand (COD), turbidity, apparent color, conductivity nitrogen content, phosphate and soluble n-hexane were determined using the method of APHA et al. (1998). The quantities of nitrate and nitrite were determined following the methods of Instituto Adolfo Lutz (1985) and Hevel and Marietta (1994), respectively.

\subsection{Biochemical analysis}

The hepatic tissue of the fish was homogenized in a Potter-Elvehjen homogenizer, in the proportion 1:5 of tissue in a Tris- $\mathrm{HCl} 50 \mathrm{mM}$ buffer at a $\mathrm{pH}$ of 7.4. The subcellular structures were broken down with a sonic dismembrator (Model 100, Fisher Scientific) and then centrifuged at $14,000 \mathrm{x} \mathrm{g}\left(5810 \mathrm{R}\right.$, Eppendorf) for 10 minutes at $4^{\circ} \mathrm{C}$, and only the supernatant was used for further biochemical analysis.

SOD activity was determined using a reaction system containing a sodium carbonate buffer of $100 \mathrm{mM}$ ( $\mathrm{pH} 10.2$ ), $17.5 \mu \mathrm{M}$ de EDTA and $1 \mathrm{mM}$ of NBT (nitrotetrazolium blue chloride). The reaction was initiated by the addition of hydroxylamine for a final concentration of $3.7 \mathrm{mM}$. The increase in absorbance was measure at $\lambda=560 \mathrm{~nm}$ by using a microplate reader (Fluorstar Optima, BMG Labtech) (Kono, 1978). One unity of SOD is expressed as a quantity of enzyme that inhibit $50 \%$ of NBT reduction. CAT activity was determined in a reaction system containing $100 \mathrm{mM}$ sodium phosphate buffer ( $\mathrm{pH} 7.0$ ), and $12 \mathrm{mM}$ of $\mathrm{H}_{2} \mathrm{O}_{2}$. The reduction in absorbance was determined at $\lambda=240 \mathrm{~nm}$ (spectrophotometer DU 640, Beckman) (Regoli et al., 1997). The total protein concentration was determined using the bicinchoninic acid method (BCA) using the reagent kit made by Sigma-Aldrich with bovine albumin serum as a standard (Smith et al., 1985). The CAT activity is expressed in International Units (U), indicating the quantity of substrate in $\mu \mathrm{mol}$ transformed into product in one minute $\left(\mu \mathrm{mol} \mathrm{min}^{-1}\right)$ and normalized as a function of the total protein concentration in the homogenate $\left(\mu \mathrm{mol} \mathrm{min}{ }^{-1} \mathrm{mg}_{\text {protein }}{ }^{-1} ; \mathrm{U} \mathrm{mg}^{-1}\right)$. 


\subsection{Data analysis}

Statistical analysis was done using Graph Prism for Windows version 5.0. The results are presented as mean \pm SEM (standard error of the mean). Statistical comparison between the groups was done using one way ANOVA, followed by the multiple pairwise Tukey "a posteriori" comparison test. Differences were considered significant for $\mathrm{p}<0.05$.

\section{RESULTS AND DISCUSSION}

The physical and chemical parameters of the water at the sites where the fish were collected are given in Table 1. At FP all of the parameters are within the reference limits except for apparent color and total phosphates. At RM, conductivity, apparent color and Nhexane are well above the recommended limits, whereas at IP, conductivity and COD are well above the reference values.

Table 1. Water parameters at sampling sites on the Una River basin.

\begin{tabular}{|c|c|c|c|c|}
\hline Parameters & $\begin{array}{l}\text { Fazenda } \\
\text { Piloto }\end{array}$ & Remédios & Ipiranga & Reference $^{a}$ \\
\hline Conductivity $\left(\mu \mathrm{S} \mathrm{cm}^{-1}\right)$ & 106.0 & 198.7 & 121.0 & $100^{\mathrm{b}}$ \\
\hline Apparent Color $\left(\mathrm{Pt}-\mathrm{Co} \mathrm{L}{ }^{-1}\right)$ & 307.0 & 191.5 & 858.0 & $15^{\mathrm{c}}$ \\
\hline Hardness $\left(\mathrm{mg} \mathrm{CaCO}_{3} \mathrm{~L}^{-1}\right)$ & 6.02 & 12.05 & 8.43 & $500^{\mathrm{d}}$ \\
\hline $\mathrm{pH}$ & 6.5 & 6.4 & 6.2 & 6.0 to 9.0 \\
\hline Turbidity (NTU) & 30.9 & 22.7 & 101.0 & 100 \\
\hline $\mathrm{COD}\left(\mathrm{mg} \mathrm{O}_{2} \mathrm{~L}^{-1}\right)$ & 8.45 & 10.75 & 64.21 & $20^{\mathrm{e}}$ \\
\hline Total Phosphates $\left(\mathrm{mg} \mathrm{L}^{-1}\right)$ & 0.3 & ND & ND & $0.1^{\mathrm{f}}$ \\
\hline N-hexane-soluble $\left(\mathrm{mg} \mathrm{L}^{-1}\right)$ & ND & 1.5 & $\mathrm{ND}^{\mathrm{f}}$ & $\begin{array}{l}\text { Virtually } \\
\text { absent }\end{array}$ \\
\hline $\begin{array}{l}\text { Total Nitrogen Kjeldahl } \\
\left(\mathrm{mg} \mathrm{L}^{-1}\right)\end{array}$ & 0.66 & 0.84 & 0.32 & $3.7^{\mathrm{g}}$ \\
\hline Nitrate $\left(\mathrm{mg} \mathrm{L}^{-1}\right)$ & $0.523 \pm 0.019$ & $0.279 \pm 0.015$ & $1.064 \pm 0.042$ & 10.0 \\
\hline Nitrite $\left(\mathrm{mg} \mathrm{L}^{-1}\right)$ & $0.042 \pm 0.014$ & $0.027 \pm 0.004$ & $0.265 \pm 0.003$ & 1.0 \\
\hline
\end{tabular}

Figure 2 shows the hepatic SOD activity of the fish. The SOD levels of fishes from IP are $60 \%$ larger than those at RM and $39.17 \%$ higher than those at FP. There is a significant difference $(p<0.05)$ in the SOD activity of fishes at RM and IP, but no difference in SOD activity for fishes from FP as compared to those from IP or RM. The hepatic SOD activity in the fish at RM had a very large variation, whereas for SOD they were within a very narrow range as compared to the fish from the other two locations. 


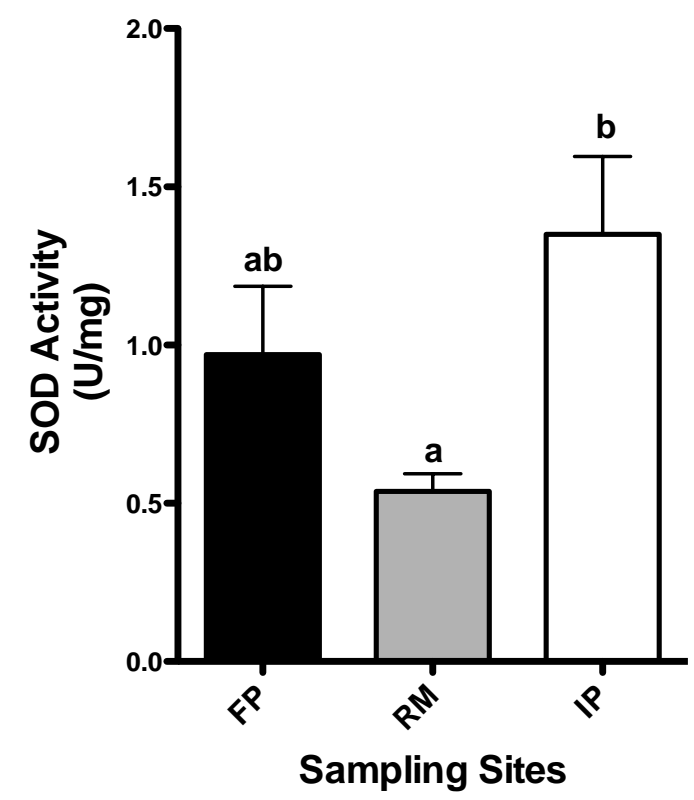

Figure 2. SOD levels in the hepatic tissues of Astyanax bimaculatus at three different points in the Una River Basin. Data presented as mean \pm SEM (standard error of the mean). Different letters above bars indicate significant differences in experimental group means $(\mathrm{p}<0.05)$.

The hepatic CAT activities of fish from three locations are shown in Figure 3. The CAT activity of fish at FP is $148.9 \%$ lower than the activity in fish at RM and $202.36 \%$ lower than those at IP and this difference is significant $(\mathrm{p}<0.005)$. However, there is no difference in the CAT activity of fishes from RM and IP. Further, the variation in CAT activity in the fishes at $\mathrm{RM}$ is very small.

Fishes are used as a model for the biomonitoring of the aquatic environment and as sentinel agents for pollutants (Sedeño-Diaz and Lopez-Lopez, 2013). The pollutants affect various organs, particularly gills, which are exposed directly to the contaminants in the environment. However, most of the pollutants are transferred to the blood and transported to the liver, which is the principal detoxification organ for xenobiotic substances. Hepatic tissue is, therefore, the place where most of the pollutants accumulate and therefore where long-term damage is most likely to occur. Most of the pollutants and their metabolites induce toxicity via oxidative stress arising from the increased production of free oxygen radicals. The antioxidant defense enzymes involved in the removal of ROS are the principal candidates for biomarkers of oxidative stress. The antioxidant defense enzymes, however, have great variability and are dependent on the organisms, organ tissues and the nature of the pollutants involved (Sole et al., 2011).

Examining Table 1, it can be seen that COD at IP is elevated. COD is elevated when there is industrial discharge and is an important test to determine the organic content of effluents that may contain toxic substances (Vidal et al., 2014). In addition, conductivity is above the reference values set by CETESB at RM and IP, indicating the presence of dissolved inorganic solids and metals (Vidal et al., 2014). Metals may occur naturally in soils and are leached into water by the action of rain, or they may be due to industrial, agricultural or other anthropogenic activity (Qu et al., 2014). Another parameter, the apparent color, is also high at IP. Iron and other metals either in nature or arising from the discharge of highly corrosive 
products could affect the water color. Copper, iron and lead, measured by CETESB near the water pumping stations on the river (S 230.' $49^{\prime \prime}$ W45 $\left.30^{\prime} 26^{\prime \prime}\right)$ indicate that the concentration of these metals increases during the months of December to February, when there are rains. Based on these factors, it may be assumed that IP and RM have a larger quantity of pollutants (of both natural and anthropic origins) as compared to FP. Hence FP may be used as reference point as it was less impacted than the other sampling locations during the period December 2013 to March 2014.

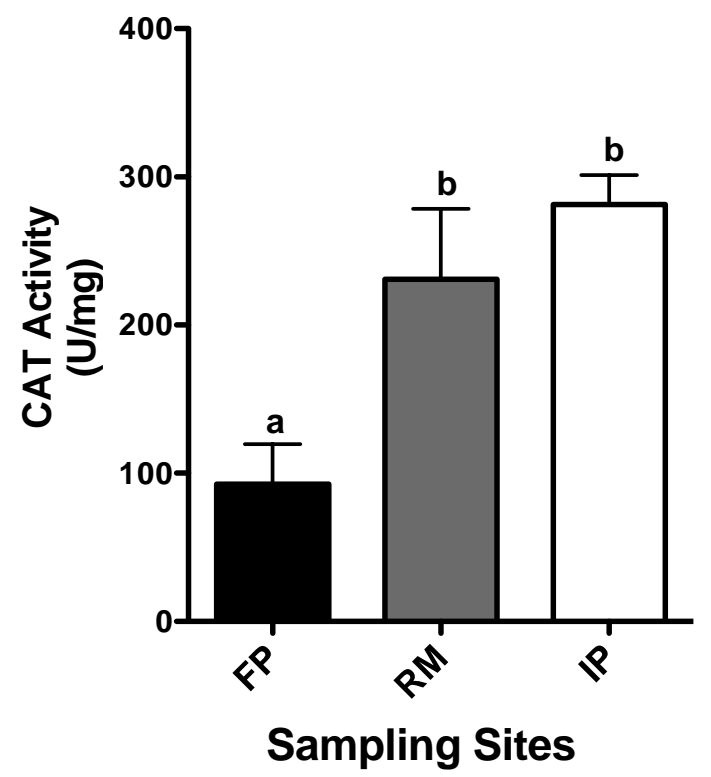

Figure 3. CAT activity in the hepatic tissues of fish, Astyanax bimaculatus, from three different locations in the Una River Basin. Data is presented as mean \pm SEM (standard error of the mean). Different letters above bars indicate significant differences in experimental group means $(\mathrm{p}<0.05)$.

SOD and CAT activity are the most widely used measures of oxidative stress. The hepatic SOD activity of Astyanax bimaculatus was greatly reduced at RM and was elevated at IP. SOD activity is elevated in the presence of heavy metals (Lushchak 2011; Farombi et al., 2007; Kanak et al., 2014). Farombi et al. (2007) have found that SOD activity is enhanced in the hepatic tissues of fish in the Ogun River, Nigeria, near industrial activity. However, there have also been studies that indicate the inhibition of SOD activity in the presence of metals (Ameur et al., 2012) or upon exposure to herbicides and pesticides (Modesto and Martinez, 2010; Sakuragui et al., 2013).

Since the exact nature of the pollutants and their seasonal variations in the Una River Basin are not known, it would be difficult to attribute the SOD activity levels to any specific substance. The reduction in SOD activity at RM could be due to the presence of chemical substances (pesticides) that inhibit the SOD, or due to suppression of SOD activity as a result of oxidative damage to the hepatic tissue, or alternately that fish have been exposed to pollutants for a short time during which the fish did not have time to adapt to the environment and increase SOD activity. SOD activity could also be depleted by prolonged exposure to pollutants at low concentrations (Pandey et al., 2003). The elevated SOD activity at IP could 
be due to adaptation of the fish to the pollutants or to brief exposure for a very short time. Sedeño-Diaz and Lopez-Lopez et al. (2012) found that SOD activity was either enhanced or inhibited depending on the concentration and seasonality of the pollutants.

Sedeño-Diaz and Lopez-Lopez (2012) found enhanced CAT activity with elevated levels of pollutants, principally hydrocarbons and pesticides. The enhanced CAT activity in the presence of herbicides and pesticides was also verified in a study with the freshwater fish Channa puncatatus (Nwani et al., 2010) and with the neotropical fish Astyanax altiparanae used to asses water quality in an agriculture area (Vieira et al., 2014). In the present work, CAT was significantly lower at FP as compared to the RM and IP.

CAT degrades the hydrogen peroxide produced by the dismutation of superoxide ion by SOD during oxidative stress. Hence an increase in SOD activity should result in increased CAT activity. However, this is not always observed in practice and appears to be species dependent (Ferreira et al., 2005; Lushchak, 2011).

\section{CONCLUSIONS}

Based on the analysis, FP could be considered a less-impacted site. Since RM is near an agricultural zone, probable runoff from fertilizers and pesticides depressed the levels of SOD and enhanced CAT. The elevated levels of SOD and CAT at IP could be due to pollutants (visible oil slicks). These results indicate the antioxidant activity of the enzymes SOD and CAT could be used as biomarkers. The possible inductor or inductors responsible for the alterations in the present work was not identified. However, alterations found in this work suggest that there may be micro pollutants that are affecting the metabolism of fish in the hydrographic basin of the Una River. Our results therefore highlight the need for further investigation to determine the presence of pollutants as such herbicides, pesticides and heavy metals, especially around the stretches of RM and IP.

\section{ACKNOWLEDGMENTS}

The authors acknowledge the support of Simone Sano Russi de Rezende and Ana Paula Costa of water analysis laboratories, the members of Fazenda Piloto specially Antonio Cortez Filho and Eduardo Galvão de Aguiar. We also would like to acknowledge National Institute of Science and Technology Antarctic Environmental Research (INCT - APA). Maria Tereza Oliveira Batista and Anne Caroline Ribeiro received the research initiation scholarship PIBIC/ CNPq (IBB_23_2013) and PIC/University of Taubaté (IBB_42_2013), respectively.

\section{REFERENCES}

ALBA-TERCEDOR, J. Macroinvertebrados acuáticos y calidad de las aguas de los ríos. In: SIMPOSIO DEL AGUA DE ANDALUCÍA - SIAGA, 4., 1996, Almería. Anais... [S.1.]: [s.n.], 1996. v. 2. p. 203-213.

AMEUR, W. B.; LAPUENTE, J.; MEGDICHEA, Y.E.; BARHOUMI, B.; TRABELSI, S.; CAMPS, L. et al. Oxidative stress, genotoxicity and histopathology biomarker responses in mullet and sea bass liver from Bizerte Lagoon. Marine Pollution Bulletine, v. 64, p. 241-251, 2012. http://dx.doi.org/10.1016/j.marpolbul.2011.11.026

AMERICAN PUBLIC HEALTH ASSOCIATION - APHA; AMERICAN WATER WORKS ASSOCIATION - AWWA; WATER ENVIRONMENTAL FEDERATION WEF. Stardard methods for the examination of water and wastewater. 20. ed.Washigton, 1998. 
BATISTA, G. T.; TARGA, M.; FIGALDO, E. C. C. Banco de dados ambientais da Bacia do Rio Una, Bacia do Rio Paraíba do Sul. Taubaté: Universidade de Taubaté; Departamento de Ciências Agrarias. Laboratório de Geoprocessamento (LAGEO), 2002. p. 1-16. Available in:

http://www.agro.unitau.br:8080/dspace/bitstream/2315/51/1/Projeto_Una_IBICT.pdf. Access in: Aug. 2014.

BEASLEY, G.; KNEALE, P. Investigating the influence of heavy metals on macroinvertebrate assemblages using Partial Canonical Correspondence Analysis (pCCA). Hydrology and Earth Systems Sciences, v. 7, p. 221-233, 2003. http://dx.doi.org/10.5194/hess-7-221-2003

BINELLI, A.; COGNI, D. Multi-biomarker approach to investigate the state of contamination of the R. Lambro/R. Po confluence (Italy) by zebra mussel (Dreissena polymorpha). Chemosphere, v. 79, p. 518-528, 2010.

http://dx.doi.org/10.1016/j.chemosphere.2010.02.033

BRASIL. Ministério da Saúde. Portaria no 2.914, de 12 de dezembro de 2011. Available in: <http://bvsms.saude.gov.br/bvs/saudelegis/gm/2011/prt2914_12_12_2011.html>.

Access in: July 2014.

BRASIL. Ministério do Meio Ambiente. Conselho Nacional do Meio Ambiente. Resolução n. 257, de 17 de março de 2005. Available in: http://www.mma.gov.br/port/conama/res /res05/res35705.pdf. Access in: Sep. 2014.

COMPANHIA DE TECNOLOGIA DE SANEAMENTO AMBIENTAL - CETESB. Água, rios e reservatórios. São Paulo, 2014. Available in: <http://www.cetesb.sp.gov.br/ agua/\%C3\%81 guas-Superficiais/34-Vari\%C3\%A1veis-de-Qualidade-das-

\%C3\%81guas\#condutividade>. Access in Mar. 2014.

CHAPMAN, D.; KIMSTACH, V. Selection of water quality variables. In: CHAPMAN, D. (Ed.). Water quality assessment: a guide to the use of biota, sediments and water in environmental monitoring. $2^{\text {nd }}$ Ed. Cambridge: UNESCO/WHO/UNEP, 1996. Cap. 3. Available in: <http://www.who.int/water_sanitation_health/resources/wqa/en/>. Access in Mar. 2014.

DAHL, J.; JOHNSON R. K.; SANDIN, L. Detection of organic pollution of streams in southern Sweden using benthic macroinvertebrates. Hydrobiologia, v. 516, p. 161-172, 2004. http://dx.doi.org/10.1023/B:HYDR.0000025264.35531.cb

FERREIRA, M.; MORADAS-FERREIRA, P.; REIS-HENRIQUES, M. A. Oxidative stress biomarkers in two resident species, mullet (Mugil cephalus) and flounder (Platichthys flesus) from a polluted site in River Douro Estuary, Portugal. Aquatic Toxicology, v. 71, p. 39-48, 2005. http://dx.doi.org/10.1016/j.aquatox.2004.10.009

FAROMBI, E. O.; ADELOWO, O. A.; AJIMOKO, Y. R. Biomarkers of oxidative stress and heavy metal levels as indicators of environmental pollution in African catfish (Clarias gariepinus) from Nigeria Ogun River. International Journal of Environmental Research and Public Health, v. 4, p. 158-165, 2007. http://dx.doi.org/10.3390/ijerph2007040011 
FONSECA, V. F.; VASCONCELOS, R. P.; FRANÇA, S.; SERAFIM, A.; LOPES, B.; COMPANY, R. et al. Modelling fish biological responses to contaminants and natural variability in estuaries. Marine Environmental Research, v. 96, p. 45-55, 2014. http://dx.doi.org/10.1016/j.marenvres.2013.10.011

GOYAL, M. M.; BASAK, A. Human catalase: looking for complete identity. Protein cell, v. 1, n. 10, p. 888-897, 2010. http://dx.doi.org/10.1007/s13238-010-0113-z

HEVEL, J. M.; MARIETTA, M. A. Nitric-oxide synthase assays, In: PARKER, L. (Ed.). Methods in enzymology. London: Academic Press, 1994.p. 250-258.

INSTITUTO ADOLFO LUTZ. Normas analíticas do Instituto Adolfo Lutz. V. 1: Métodos químicos e físicos para análise de alimentos. 3. ed. São Paulo: IMESP, 1985. p. $317-$ 319.

KANAK E. G.; DOGAN Z.; EROGLU A.; ATLI G.; CANLI M. Effects of fish size on the response of antioxidant systems of Oreochromis nilocicus following metal exposure. Fish Physiology and Biochemistry, v. 40, n. 4, p. 1083-1091, 2014. http://dx.doi.org/10.1007/s10695-014-9907-x

KONO, Y. Generation of superoxide radical during autoxidation of hydroxylamine and an assay for superoxide dismutase. Archives of Biochemistry and Biophysics, v. 186, p. 189-195, 1978.

LUSHCHAK V. I. Environmentally induced oxidative stress in aquatic animals. Aquatic Toxicology, v. 101, p. 13-30, 2011. http://dx.doi.org/10.1016/j.aquatox.2010.10.006

McCARTHY, J. F.; SHUGART, L. Biomarkers of environmental contamination. Boca Raton: Lewis Publishers, 1990.

MODESTO, K. A.; MARTINEZ, C. B. R. Roundup causes oxidative stress in liver and inhibits acetylcholinesterase in muscle and brain of the fish Prochilodus lineatus. Chemosphere, v. 78, p. 294-299, 2010.

http://dx.doi.org/10.1016/j.chemosphere.2009.10.047

MOREIRA, T. N.; NUNES, E. A.; LEAL, M. E.; SCHULZ, U. H.; LEMOS, C. T. Influência dos métodos de captura de peixes na avaliação genotóxica utilizando diferentes tecidos de Astyanax fasciatus (Osteichthyes, Characidae). Journal of Brazilian Society of Ecotoxicology, v. 5, p. 1-7, 2010. http://dx.doi.org/10.5132/jbse.2010.01.001

NWANI, C. D.; LAKRA, W. S.; NAQPURE, N. S.; KUMAR, R.; KUSHWAHA, B.; SRIVASTAVA, S. K. Toxicity of the herbicide atrazine: effects on lipid peroxidation and activities of antioxidant enzymes in the freshwater fish Channa Punctatus. International Journal of Environmental Research and Public Health, v. 7, p. 32983312, 2010. http://dx.doi.org/10.3390/ijerph7083298

PANDEY, S.; PARVEZ, S.; SAYEED, I.; HAQUE, R.; BIN-HAFEEZ, B.; RAISUDDIN, S. Biomarkers of oxidative stress: a comparative study of river Yamuna fish Wallago attu (B1. \& Schn.). Science of the Total Environment, v. 309, p. 105-115, 2003. http://dx.doi.org/10.1016/S0048-9697(03)00006-8

QU, R.; FENG, M.; WANG, X.; QIN, L.; WANG, C.; WANG, Z. \& WANG, L. Metal accumulation and oxidative stress biomarkers in liver of freshwater fish Carassius auratus following in vivo exposure to waterborne zinc. Aquatic toxicology, v. 150, p. 9-16, 2014. http://dx.doi.org/10.1016/j.aquatox.2014.02.008 
REGOLI, F.; PRINCIPATO, G. B.; BERTOLI, E.; NIGRO, M.; ORLANDO, E. Biochemical characterization of the antioxidant system in the scallop Adamussium colbecki, a sentinel organismo for monitoring the Antarctic environment. Polar Biology, v. 17, p. 251-258, 1997.

SEDEÑO-DIAZ, J. E.; LÓPEZ-LÓPEZ, E. Fresh water fish as sentinel organism: from the molecular to the population level, a Review. In: TURKER, H. (Ed.). New advances and contributions to fish biology. 2013. http://dx.doi.org/10.5772/54825

SMITH, P. K. et al. Measurement of protein using bicinchoninic acid. Analytical Biochemistry, v. 150, n. 1, p. 76-85, 1985. http://dx.doi.org/10.1016/00032697(85)90442-7

SOLE, M.; BAENA, M.; ARNAUA, S.; CARRASSONB, M.; MAYNOUA, F.; CARTES, J. E. Muscular cholinesterase activites and lipid peroxidation leves as biomarkers in several Mediterranean marine fish species and their relationship with ecological variabels. Enviromental International, v. 36, p. 202-211, 2011. http://dx.doi.org/10.1016/j.envint.2009.11.008

SAKURAGUI, M. M.; PAUlinO, M. G.; PEREIRA, C. D. S.; CARVAlHO, C. S.; SADAUKAS-HENRIQUE, H.; FERNANDES, M. N. Integrated use of antioxidant enzymes and oxidative damage in two fish species to assess pollution in man made hydoelectic reservoirs. Environmental Pollution, v. 178, p. 41-51, 2013. http://dx.doi.org/10.1016/j.envpol.2013.02.032

TRUJILLO-JIMÉNEZ, P.; SEDEÑO-DÍAZ, J. E.; CAMARGO, J. A.; LÓPEZ-LÓPEZ, E. Assessing environmental conditions of the Río Champotón (México) using diverse indices and biomarkers in the fish Astyanax aeneus (Günther, 1860). Ecological Indicators, v. 11, p. 1636-1646, 2011. http://dx.doi.org/10.1016/j.ecolind.2011.04.007

VIDAL, L.; DOMINI, C. E.; CANALS, A. Main parameters and assays involved with the organic pollution of water. In: NOLLET, L. M. L.; DEBELDER, L. S. P. Handbook of water quality analysis. $3^{\text {rd }}$. Edition. Boca Raton: CRC Press, 2014.

VIEIRA, C. E. D.; ALMEIRA, M. S.; GALINDO, B. A.; PEREIRA, L.; MARTINEZ, C. B. R. Integrated biomarker response index using a neotropical fish to assess the water quality in agricultural áreas. Neotropical Ichtyology, v. 12, p. 153-164, 2014. http://dx.doi.org/10.1590/S1679-62252014000100017 